\title{
Hepatoprotective Effect of Methanol Extract of Justicia carnea Leaves on Carbon Tetrachloride-Intoxicated Albino Rats
}

\author{
Ukpabi-Ugo JC ${ }^{1 *}$, Ndukwe PAC $^{2}$, Iwuoha $\mathrm{AG}^{1}$
}

${ }^{1}$ Department of Biochemistry, College of Natural Sciences, Michael Okpara University of Agriculture, Umudike, Abia State, Nigeria; ${ }^{2}$ Department of Zoology and Environmental Biology, College of Natural Sciences, Michael Okpara University of Agriculture, Umudike, Abia State, Nigeri

\begin{abstract}
Introduction: Hepatotoxicity can be caused by drugs overdose (in some cases even when the drugs are administered in therapeutic doses). This may damage the liver temporarily or permanently. The reason for this study is to evaluate the amount of damage caused by carbon tetrachloride $\left(\mathrm{CCl}_{4}\right)$ on liver and establish a dose-dependent treatment and prevention with Justicia carnea leaves extract.
\end{abstract}

Aim: Hepatoprotective effect of methanol extract of Justicia carnea leaves on carbon tetrachloride intoxicated albino rats was investigated.

Methods: A total of thirty-five female wistar albino rats were used for the study and were grouped into 7 groups (I-VII) of 5 rats each. Group I served as normal control which received only feed and water, group II served as $\mathrm{CCl}_{4}^{-}$ treated control receiving $0.5 \mathrm{mg} / \mathrm{kg}$ bodyweight $(\mathrm{bw})$ in of $\mathrm{CCl}_{4}$ alone in olive oil $(1: 1 \mathrm{v} / \mathrm{v})$, group III served as extract control which received $1000 \mathrm{mg} / \mathrm{kg}$ bw of methanol extract of Justicia carnea (JC) only, groups IV, V and VI received 200,500 and $1000 \mathrm{mg} / \mathrm{kg}$ bw of methanol extract of Justician carnea respectively prior to $\mathrm{CCl}_{4}$ administration while group VII received $100 \mathrm{mg} / \mathrm{kg}$ bw of silymarin as a standard drug prior to $\mathrm{CCl}_{4}$ administration. Some biochemical parameters were evaluated using biochemical methods.

Results: The activities of aspartate transaminase (AST), alanine transaminase (ALT), alkaline phosphatase (ALP) and bilirubin levels showed a significant $(\mathrm{p}<0.05)$ increase in the group treated with $\mathrm{CCl}_{4}$ only when compared with the normal control while total protein and albumin levels showed a significant $(\mathrm{p}<0.05)$ decrease in the group treated with $\mathrm{CCl}_{4}$ only when compared with the normal control. However, groups pre-treated with different doses of $200,500$ and $1000 \mathrm{mg} / \mathrm{kg}$ bw of Justicia carnea showed a significant ( $<<0.05)$ decrease in the activities of ALT, AST and ALP, and bilirubin level while total protein and albumin levels increased significantly $(\mathrm{p}<0.05)$ when compared with the rats treated with $\mathrm{CCl}_{4}$ alone. Histopathological examinations of sections of the liver collected from the different groups showed that the normal control had a normal liver architecture compared to the group treated with $\mathrm{CCl}_{4}$ alone which showed a diffuse vacuolar degeneration and coagulative necrosis of the hepatocytes. However, groups pre-treated with different doses of the extract showed lesser necrosis and a better liver architecture compared with the group treated with $\mathrm{CCl}_{4}$ alone.

Conclusion: The results of this study suggest that the methanol extract of Justicia carnea may exhibit hepatoprotective properties that may be effective in the management of liver toxicity.

Keywords: Carbon tetrachloride; Liver; Hepatoprotective; Justicia carnea

\section{INTRODUCTION}

Medicinal plants have been established to possess beneficial properties for the management, and prevention of various ailments because they have been discovered to contain bio-active compounds called phytochemicals [1] and secondary metabolites that can protect humans against diseases [2]. Examples of some plants used in the treatment and prevention of hepatotoxicity include: Casurina equisetifolia, Cajanus cajan, Glycosmis pentaphylla, Bixa orella, Argemone mexicans, Physalis minima, and Caesalpinia

Correspondence to: Ukpabi-Ugo JC, Department of Biochemistry, College of Natural Sciences, Michael Okpara University of Agriculture, Umudike, Abia State, Nigeria, Tel: +234(0)9027427974; E-mail: jesychi@gmail.com

Received: February 20, 2019; Accepted: April 10, 2019; Published: April 17, 2019

Citation: Ukpabi-Ugo JC, Ndukwe PAC, Iwuoha AG (2019) Hepatoprotective Effect of Methanol Extract of Justicia carnea Leaves on Carbon Tetrachloride-Intoxicated Albino Rats. Biochem Anal Biochem 8:381. doi: 10.35248/2161-1009.19.8.381.

Copyright: (C) 2019 Ukpabi-Ugo JC, et al. This is an open-access article distributed under the terms of the Creative Commons Attribution License, which permits unrestricted use, distribution, and reproduction in any medium, provided the original author and source are credited. 
bonduc [3]. Many synthetic drugs are available for prevention and treatment of hepatotoxicity, but due to the cost of procuring these drugs, and the side effects associated with their use, attention is currently being focused on use of medicinal plants products in the prevention and management of various ailments [4,5].

Hepatotoxicity refers to liver dysfunction or liver damage that is associated with an overload of drugs or xenobiotic [6]. It is a chemical-driven liver damage. Certain medicinal agents, when taken in overdoses and sometimes even when introduced within therapeutic ranges, may injure the liver. Other chemical agents, such as those used in the laboratory and industries, natural chemicals (e.g. microcystrins) and herbal remedies can also induce hepatotoxicity [7]. The body is exposed daily to several environmental and biological toxins that may damage the liver and pose serious health problems. Hepatotoxicity may result not only from direct toxicity of the primary compound but also from a relative metabolite or from an immunologically-mediated response affecting hepatocytes billary epithelial cells and/or liver vascularture [8].

Justicia carnea is a flowering plant that belongs to Acanthaceae family. The genus Justicia was named after a Scottish Gardner James Justice, in the $18^{\text {th }}$ century [9]. It is popularly used in eastern Nigeria as blood tonic prepared by decoction [9]. Several species of Justicia are traditionally used in the management of several ailments such as: inflammation, gastrointestinal disorders, diarrhoea, liver diseases, rheumatism and arthritis $[10,11]$. They also possesses anti-inflammatory, anti-allergy, anti-tumor, anti-viral and analgesic activities [12] and antioxidant activity [13].

Despite the scientific use of Justicia carnea, there is little knowledge on the scientific and experimented evidence on the use of Justicia carnea leaves in prevention and treatment of hepatotoxicity in experimental animals therefore; this study was designed to investigate the hepatoprotective effect of methanol extract of Justicia carnea against carbontetrachloride $\left(\mathrm{CCl}_{4}\right)$-induced hepatotoxicity in albino rats.

\section{MATERIALS AND METHODS}

\section{Collection and identification of plant}

Fresh leaves of Justicia carnea commonly known as flamingo was collected from Oborji in Umuana village, Umuahia North Local Government Area of Abia State, and from Amoba village, and Umudike village both in Ikwuano Local Government Area of Abia State. The plant was identified at the Taxonomy unit of the Department of Plant Science and Biotechnology, College of Natural Sciences, Michael Okpara University of Agriculture, Umudike.

\section{Preparation of plant material}

The freshly collected leaves were washed with clean water and airdried. The dried leaves were pulverised into coarse powder by use of a miller, macerated in methanol and was stirred intermittently for 72 hours to facilitate extraction. The extract was filtered using Whatman no.4 filter paper into different pre-weighed beakers and the filtrate was concentrated by evaporation in a water bath at $60^{\circ} \mathrm{C}$ to obtain the crude extract. A stock solution of $0.6 \mathrm{~g} / \mathrm{ml}$ of the plant extract was prepared and stored in the refrigerator. The volume of stock to be administered was calculated based on the individual body weight of each animal, using the formula:
Volume $=\frac{D \times P}{\mathrm{C}}$

Where; $\mathrm{D}=$ dose to be administered, $\mathrm{P}=$ body weight of animal in $\mathrm{kg}$, $\mathrm{C}=$ concentration of the stock.

\section{Animals}

A total of thirty-five apparently healthy female Wistar albino rats weighing between 50-100 g were obtained from the animal breeding unit of the College of veterinary medicine, University of Nigeria, Nsukka. All animal experiments were conducted in compliance with NIH guidelines for Care and Use of Laboratory Animals (Pub. No. 85-23, Revised 1985). The study was approved by institutional animal ethical committee and the norms were observed strictly. The animals were housed in well-ventilated Stainless Steel cages under standard laboratory conditions and were given commercial rat feed and water ad libitum. The animals were allowed to acclimatize for 1 week before commencement of the actual experiment (Figures 1-7).

\section{EXPERIMENTAL DESIGN}

Thirty-five female wistar albino rats were used for the study. The rats were distributed into 7 groups of five rats each by random sampling method. The hepatoprotective activity of the plant extract was tested using $\mathrm{CCl}_{4}$ model. The experimental groups are illustrated as follows:

\section{Group I: Normal control,}

Group II: $\mathrm{CCl}_{4}$-treated control which received single intraperitoneal dose of $0.5 \mathrm{ml} / \mathrm{kg}$ bw of $\mathrm{CCl}_{4}$ in olive oil $(1: 1 \mathrm{v} / \mathrm{v})$,

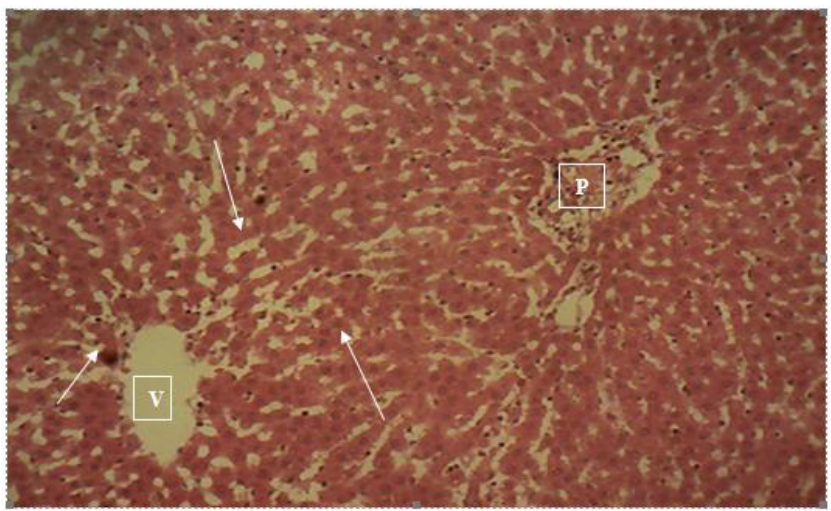

Figure 1: Photomicrograph of the liver of rats fed with feed and water only (normal control).

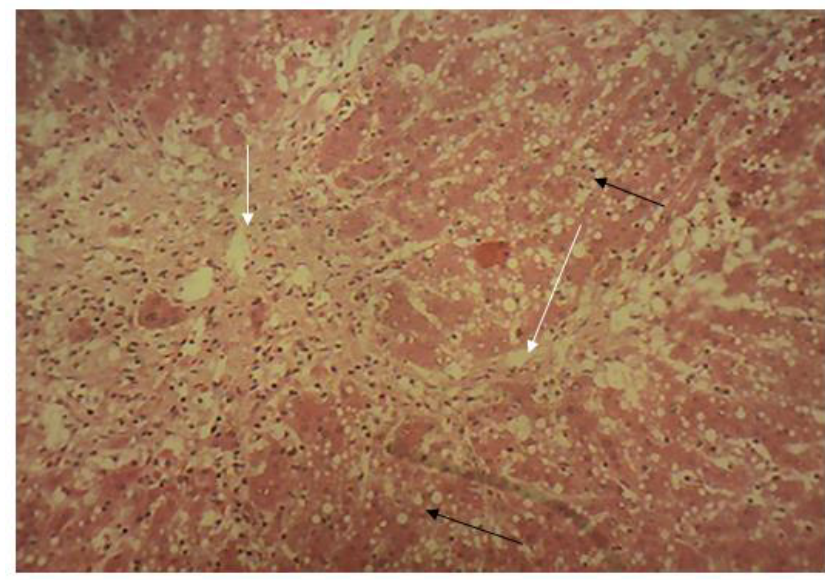

Figure 2: Photomicrograph of the liver of rats treated with $0.5 \mathrm{ml} / \mathrm{kg}$ bw of $\mathrm{CCl}_{4}$ alone ( $\mathrm{CCl}_{4}$-treated control group). 


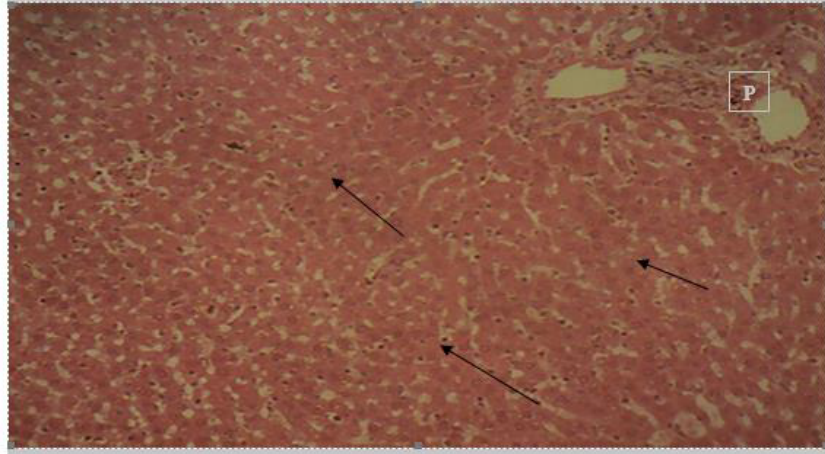

Figure 3: Photomicrograph of the liver of rats treated with $1000 \mathrm{mg} / \mathrm{kg} \mathrm{bw}$ of Justicia carnea extract alone (extract control).

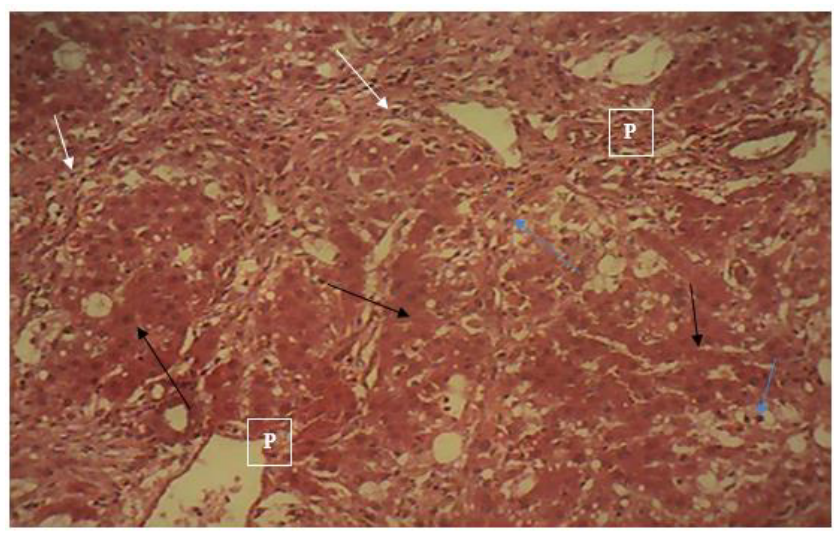

Figure 4: Photomicrograph of the liver of rats pre-treated with $200 \mathrm{mg} / \mathrm{kg}$ bw of Justicia carnea leaves extract prior to $\mathrm{CCl}_{4}$ administration.

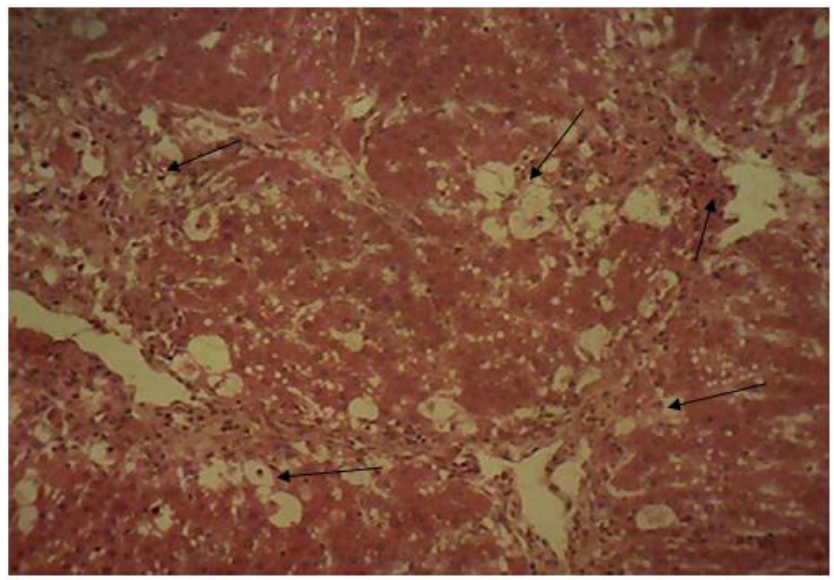

Figure 5: Photomicrograph of the liver of rats pre- treated with $500 \mathrm{mg} / \mathrm{kg}$ bw of Justicia carnea leaves extract prior to $\mathrm{CCl}_{4}$ administration.

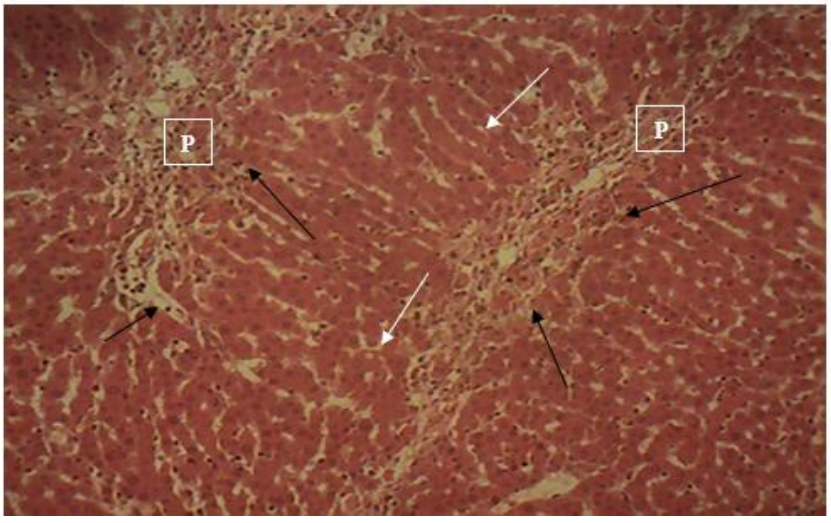

Figure 6: Photomicrograph of the liver of rats pre-treated with $1000 \mathrm{mg} /$ $\mathrm{kg}$ bw of Justicia carnea leaves extract prior to $\mathrm{CCl}_{4}$ administration.

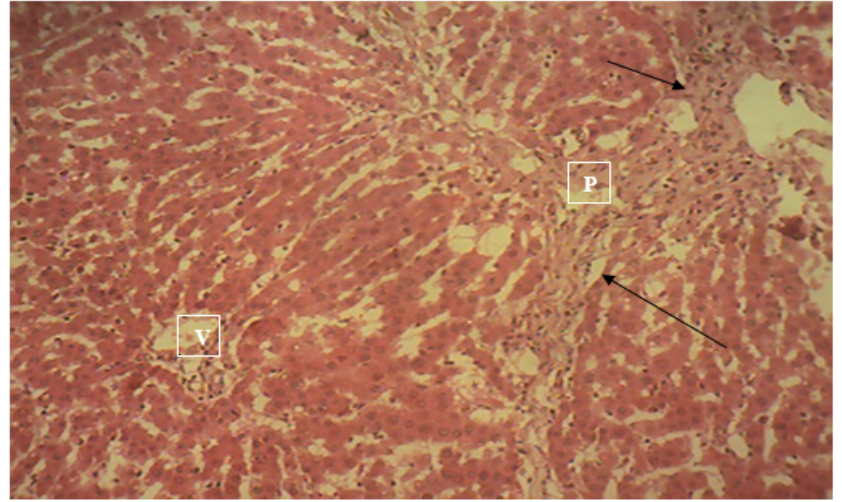

Figure 7: Photomicrograph of the liver of rats pre-treated with $100 \mathrm{mg} / \mathrm{kg}$ bw of Silymarin prior to $\mathrm{CCl}_{4}$ administration.

Group III: Extract control which received $1000 \mathrm{mg} / \mathrm{kg}$ bw of methanol extract of Justicia carnea only.

Group IV: $200 \mathrm{mg} / \mathrm{kg}$ bw of methanol extract of Justicia carnea and $0.5 \mathrm{ml} / \mathrm{kg}$ bw of $\mathrm{CCl}_{4}$ in olive oil $(1: 1 \mathrm{v} / \mathrm{v})$,

Group V: $500 \mathrm{mg} / \mathrm{kg}$ bw of methanol extract of Justicia carnea and $0.5 \mathrm{ml} / \mathrm{kg}$ bw of $\mathrm{CCl}_{4}$ in olive oil $(1: 1 \mathrm{v} / \mathrm{v})$,

Group VI: $1000 \mathrm{mg} / \mathrm{kg}$ bw of methanol extract of Justicia carnea and. $0.5 \mathrm{ml} / \mathrm{kg}$ bw of $\mathrm{CCl}_{4}$ in olive oil $(1: 1 \mathrm{v} / \mathrm{v})$,

Group VII: positive control which received $100 \mathrm{mg} / \mathrm{kg}$ bw of silymarin and $0.5 \mathrm{ml} / \mathrm{kg}$ bw of $\mathrm{CCl}_{4}$ in olive oil $(1: 1 \mathrm{v} / \mathrm{v})$.

\section{Induction of hepatotoxicity}

Carbon tetrachloride induced-hepatotoxicity was achieved by injecting a single dose of $\mathrm{CCl}_{4}(0.5 \mathrm{ml} / \mathrm{kg}$ bw, $1: 1$ in olive oil $)$ [14]. The induction was done 72 hours (twice a week) after pretreatment with the plant extract and standard drug (Silymarin) for 21 days. Food was withdrawn for 12 hours before administration of carbon tetrachloride $\left(\mathrm{CCl}_{4}\right)$ to enhance the acute liver toxicity.

\section{Collection and preparation of blood samples and organ}

After the completion of induction and treatment for 21 days, the animals were fasted over night before blood collection. The animals were euthanized by cervical dislocation. With the help of a surgical scissors, each animal was opened from thorax to abdomen and blood was collected by cardiac puncture with the aid of a $5 \mathrm{ml}$ hypodermic syringe and needle into an anti-coagulant-free bottles. The liver was excised immediately and fixed in $10 \%$ formalin for histological assessment of hepatic damage. Serum was separated by centrifugation and stored in a refrigerator.

\section{Determination of aspartate aminotransferase activity (AST)}

The activity of serum AST was determined by the method described in previous study [15].

Procedure: The blank sample test tubes were set up in duplicates. The AST substrate buffer $(0.5 \mathrm{ml})$ was pipette into both the reagent blank $(\mathrm{B})$ and sample test $(\mathrm{T})$ respectively, each containing phosphate buffer, L-aspartate and $\boldsymbol{\alpha}$-oxoglutarate. A volume of 0.1 $\mathrm{ml}$ of serum sample was pipette into the sample test tubes only and mixed thoroughly. Then $0.1 \mathrm{ml}$ of distilled water was added to the reagent blank $(\mathrm{B})$. The entire reaction medium was well mixed and incubated for $30 \mathrm{~min}$ in a water bath at $37^{\circ} \mathrm{C}$, and $\mathrm{pH}$ 7.4.

Immediately after incubation, 2,4-dinitrophenylhdrazine $(0.5 \mathrm{ml})$ 
was added to the reagent blank (B) and the sample test (T) tubes, mixed thoroughly and allowed to stand for exactly $20 \mathrm{~min}$ at $25^{\circ} \mathrm{C}$. Finally, sodium solution $(5.0 \mathrm{ml})$ was added to each of the blank (B) and reagent test $(\mathrm{T})$ tubes. The absorbance of sample test was read against the reagent blank after $5 \mathrm{~min}$ at $546 \mathrm{~nm}$. The activity of AST in human serum was obtained from a standard curve provided by Randox Company.

\section{Determination of alanine transferase activity (ALT)}

The activity of serum ALT was determined by the method described in previous study [15].

Procedure: The ALT substrate phosphate buffer $(0.5 \mathrm{ml})$ was pipette into two sets of test tubes labelled B (Sample Blank) and T (Sample Test) respectively. The serum sample $(0.1 \mathrm{ml})$ was added to the sample test $(\mathrm{T})$ only and mixed properly. The tubes were then incubated for exactly $30 \mathrm{~min}$ in a water bath at a temperature of $37^{\circ} \mathrm{C}$.

2,4-Dinitrophenylhydrazine $(0.5 \mathrm{ml})$ was added to the both the test tubes immediately after the incubation. Also serum sample $(0.1 \mathrm{ml})$ was added to the sample blank (B) only. The entire medium was mixed thoroughly and allowed to stand for exactly $20 \mathrm{~min}$ at $25^{\circ} \mathrm{C}$. Subsequently, $5.0 \mathrm{ml}$ of $\mathrm{NaOH}$ was added to both the test tubes and also mixed thoroughly. Absorbance of the sample test was read against the blank after $5 \mathrm{~min}$ at $540 \mathrm{~nm}$.

\section{Determination of alkaline phosphatase activity (ALP)}

The activity of ALP was estimated by the method described in previous study [16].

Procedure: Distilled water $(0.1 \mathrm{ml})$ was pipette into the two sets of test tubes labeled SA (Sample) and ST (Standard respectively). Then one drop each of the chromogen substrate (2-amino 2-methyl1-propanol) was added to the distilled water in each of the two sets of test tubes. Their contents were mixed and incubated at $37^{\circ} \mathrm{C}$ for 2 min in a water bath.

After which $1.0 \mathrm{ml}$ of phenol was added to the standard test tube (ST) only, followed by the addition of serum sample $(0.1 \mathrm{ml})$ to the sample test (SA). The contents of the tubes were also mixed individually and incubated at $37^{\circ} \mathrm{C}$ for $2 \mathrm{~min}$ in a water bath. Five millimetres $(5.0 \mathrm{ml})$ of a colour developer $\left(\mathrm{NaHPO}_{4}\right)$ was added to each of the tubes. Absorbance of the sample against the blank (water) was read at a wavelength of $550 \mathrm{~nm}$. The activity of alkaline phosphatase in the serum was obtained from the formula below:

$A L P(\mu / L)=\frac{S A O \cdot D}{S T O \cdot D} \times 30$

Where: SA O.D=sample optical density

ST O.D=Standard optical density.

\section{Determination of serum total bilirubin concentration}

Serum total Bilirubin concentration was determined by the endpoint colorimetric method as described in previous study [17].

Procedure: Test tubes were labeled blank, standard, control and test. Total bilirubin was prepared by adding one drop of sodium nitrite (reagent 1) to $0.2 \mathrm{ml}$ of sulfanilic acid and $\mathrm{HCl}$ (reagent 2). The solution obtained $(1 \mathrm{ml})$ was then transferred to all the test tubes and was then allowed to incubate for $10 \mathrm{~min}$ at room temperature. Caffeine reagent (reagent 3$)(1 \mathrm{ml})$ was added to the mixture and was incubated for $10 \mathrm{~min}$. The absorbance of the resulting mixture was measured at $555 \mathrm{~nm}$ against reagent blank. Total bilirubin in the sample was calculated using the formula:

Total biirubin $(\mathrm{mg} / \mathrm{dl})=\frac{\text { OD of sample }}{\text { Od of standard }} \times$ Concentration of standard

Where: OD is the optical density.

\section{Determination of serum total protein (TP) concentration}

The concentration of total protein was determined by colorimetric method as described in previous study [18].

The measurement procedure was done as follows:

Wavelength $540 \mathrm{~nm}$

Temperature $25^{\circ} \mathrm{C}$

Cuvette $1 \mathrm{~cm}$ light path

Zero adjustment Reagent blank.

The sample was mix thoroughly and incubated for $15 \mathrm{~min}$ at 30 $37^{\circ} \mathrm{C}$ and allowed for $5 \mathrm{~min}$ at room temperature. The absorbance of the test sample against reagent blank was measured. The total protein was then calculated using the formula:

Total protein concentration=190 $\times$ A sample $(\mathrm{mg} / \mathrm{dl})$.

\section{Determination of serum albumin (ALB) concentration}

The serum ALB concentration was estimated by the method as described in previous study [19].

Procedure: Three millilitre of bromocresol green (BCG) was dispensed into each of the tubes labeled reagent blank, standard and sample containing $0.01 \mathrm{ml}$ distilled water, $0.01 \mathrm{ml}$ standard albumin and $0.01 \mathrm{ml}$ test serum respectively. The mixture was then incubated for $5 \mathrm{~min}$ at $25^{\circ} \mathrm{C}$ in a water bath. After the incubation, the absorbance of the sample (Asample) and that of the standard (Astandard) against the reagent blank were read using a colorimeter at a wavelength of $578 \mathrm{~nm}$. The values obtained were used to calculate the albumin concentration using the formula:

Albumin concentration $(g / d l)=\frac{\text { A sample }}{\text { A standard }} \times$ Concentration of standard

\section{HISTOLOGICAL EXAMINATION}

The liver was excised, washed in $0.9 \%$ saline, weighed and transferred into ice cold containers for biochemical assay. The excised liver tissues were collected in a sterile universal container containing $10 \%$ neutral formalin. They were processed and embedded in paraffin wax to provide a hard support for sectioning. Every third section was mounted in glass slide and stained with haematoxylin and eosin and photomicrographed.

\section{STATISTICAL ANALYSIS}

Data obtained was analyzed using one-way analysis of variance (ANOVA) and the results were expressed as mean \pm standard deviation. Significance level was accepted at the level of $p<0.05$. LSD was used for the intergroup comparison.

\section{RESULTS}

Effect of methanol leaf extract of Justicia carnea on serum liver marker enzymes in $\mathrm{CCl}_{4}$ intoxicated rats

The results of the effect of methanol leaf extract of Justicia carnea 
on serum liver marker enzymes activities in $\mathrm{CCl}_{4}$ intoxicated rats as shown in Table 1 , showed that there was a significant $(\mathrm{p}<0.05)$ increase in the ALT, AST and ALP activities in $\mathrm{CCl}_{4}$-treated control when compared with the normal control. However, a significant $(p<0.05)$ decrease was observed in AST, ALT and ALP activities in the groups pre-treated with $200 \mathrm{mg} / \mathrm{kg} \mathrm{bw}, 500 \mathrm{mg} / \mathrm{kg}$ bw, $1000 \mathrm{mg} / \mathrm{kg}$ bw of methanol extract of Justicia carnea and the group pre-treated with $100 \mathrm{mg} / \mathrm{kg}$ bw of silymarin when compared with $\mathrm{CCl}_{4}$-treated control.

\section{Effect of methanol leaf extract of Justicia carnea on serum albumin (ALB) and total protein (TP) concentration $\mathrm{CCl}_{4}$ intoxicated rats}

The results of effect of methanol leaf extract of Justicia carnea on albumin and total protein concentrations in $\mathrm{CCl}_{4}$-intoxicated rats shown as in Table 2 showed that there was a significant $(p<0.05)$ decrease in serum albumin and total protein concentrations in the $\mathrm{CCl}_{4}$-treated control when compared with the normal control. However, a significant $(\mathrm{p}<0.05)$ increase was observed in serum albumin (ALB) and total protein (TP) concentrations in the groups pre-treated with $200 \mathrm{mg} / \mathrm{kg}, 500 \mathrm{mg} / \mathrm{kg}$ and $1000 \mathrm{mg} / \mathrm{kg}$ of Justicia carnea when compared with $\mathrm{CCl}_{4}$-treated control in a dose-dependent manner.

Table 1: Determination of serum total protein (TP) concentration.

\begin{tabular}{lccc}
\hline & Blank & Standard & Sample \\
\hline Reagent/R1 & $1000 \mu \mathrm{l}$ & $1000 \mu \mathrm{l}$ & $1000 \mu \mathrm{l}$ \\
\hline Reagent/R4 & $\ldots$ & $25 \mu \mathrm{l}$ & $\ldots$ \\
\hline Serum & $\ldots$ & $\ldots$ & $25 \mu \mathrm{l}$ \\
\hline
\end{tabular}

\section{Effect of methanol leaf extract of justicia carnea on serum total bilirubin concentration in $\mathrm{CCl}_{4}$ intoxicated rats}

The results of the effect of methanol leaf extract of Justicia carnea on serum total bilirubin concentration in $\mathrm{CCl}_{4}$ intoxicated rats shown in Table 3 showed that there was a significant $(p<0.05)$ increase in serum total bilirubin concentration in $\mathrm{CCl}_{4}$-treated control when compared with the normal control. However, the group pre-treated with 200, 500 and 1000 (mg/ kg bw) of the Justicia carnea extract and $100 \mathrm{mg} / \mathrm{kg}$ bw of silymarin, showed a significant $(\mathrm{p}<0.05)$ decrease in total bilirubin concentration when compared with the $\mathrm{CCl}_{4}$-treated control (Table 4).

\section{HISTOPATHOLOGICAL RESULTS}

Sections of the liver collected from the animals in this group showed the normal hepatic histo-architecture for laboratory rats. Normal hexagonal; mono-nucleate to bi-nucleate hepatocytes arranged in interconnecting cords (white arrow) were observed. The hepatic cords were arranged in a radiating manner around the central veins. The portal areas showed the normal constituents of the portal triads (hepatic artery, hepatic vein and bile duct). Central vein (V); Portal area (P); H\&E x160 (Figure 1)..

Sections of the liver collected from the animals in this group showed a diffuse vacuolar degeneration and coagulative necrosis of the hepatocytes (black arrow), the affected hepatocytes show varying sizes of clear vacuoles in their cytoplasm. Mild fibrosis of the peri-lobular connective tissue was also observed (white arrow); H\&E x160 (Figure 2).

Sections of the liver collected from the animals in this group

Table 2: Effect of methanol leaf extract of Justicia carnea on serum liver marker enzymes in $\mathrm{CCl}_{4}$ intoxicated rats.

\begin{tabular}{ccccc}
\hline Groups & Treatment & \multicolumn{3}{c}{ Mean enzyme activity (U/L) } \\
\cline { 3 - 5 } & & AST & ALT & ALP \\
\hline I. & Feed+water only (normal control) & $26.00 \pm 1.58^{\text {ad }}$ & $18.40 \pm 1.67^{\text {ad }}$ & $36.10 \pm 3.32^{\text {ad }}$ \\
\hline II. & $\mathrm{CCl}_{4}$-treated control & $69.8 \pm 3.77^{\text {bc }}$ & $55.60 \pm 10.81^{\text {bc }}$ & $82.74 \pm 19.33^{\text {bc }}$ \\
\hline III & Extract alone (extract control) & $24.00 \pm 4.18^{\text {ad }}$ & $16.80 \pm 1.48^{\text {ad }}$ & $30.53 \pm 3.00^{\text {ad }}$ \\
\hline IV & $\mathrm{CCl}_{4}+200 \mathrm{mg} / \mathrm{kg} \mathrm{bw}$ of J. c extract & $40.60 \pm 3.98^{\text {bd }}$ & $32.00 \pm 3.16^{\text {bd }}$ & $61.05 \pm 1.46^{\text {bd }}$ \\
\hline V & $\mathrm{CCl}_{4}+500 \mathrm{mg} / \mathrm{kg}$ bw of J.c extract & $39.20 \pm 5.81^{\text {bd }}$ & $30.40 \pm 2.07^{\text {bd }}$ & $64.21 \pm 4.17^{\text {bd }}$ \\
\hline VI. & $\mathrm{CCl}_{4}+1000 \mathrm{mg} / \mathrm{kg}$ bw of J.c extract & $34.00 \pm 4.84^{\text {bd }}$ & $24.80 \pm 3.12^{\text {bd }}$ & $44.95 \pm 3.51^{\text {ad }}$ \\
\hline VII & $\mathrm{CCl}_{4}+$ Silymarin & $44.40 \pm 2.61^{\text {bd }}$ & $31.60 \pm 1.67^{\text {bd }}$ & $62.42 \pm 3.55^{\text {bd }}$ \\
\hline
\end{tabular}

$\mathrm{n}=5$ rats in each group. $\mathrm{p}<0.05$ were considered significant. Values are expressed as mean \pm standard deviation. Values with different superscript (a, b) in the same column are significantly different when comparing other groups with the normal control.

Values with different superscript $(c, d)$ in the same column are significantly different when comparing other groups with the $\mathrm{CCl}_{4}$-treated group.

Table 3: Effects of methanol extract of Justicia carnea leaf extract on serum albumin (ALB) and total protein (TP) concentrations in CCl ${ }_{4}$ intoxicated rats.

\begin{tabular}{|c|c|c|c|}
\hline \multirow[t]{2}{*}{ Groups } & \multirow[t]{2}{*}{ Treatment } & \multicolumn{2}{|c|}{ Mean concentration $(\mathrm{mg} / \mathrm{dl})$} \\
\hline & & Total protein (TP) & Albumin (ALB) \\
\hline I. & Feed+water (Normal control) & $6.56 \pm 0.02^{\mathrm{ad}}$ & $3.83 \pm 0.30^{\mathrm{ad}}$ \\
\hline II. & $\mathrm{CCl}_{4}$-treated control & $4.63 \pm 0.27^{\mathrm{bc}}$ & $1.86 \pm 0.59^{\mathrm{bc}}$ \\
\hline III. & Extract alone (extract control) & $6.95 \pm 0.88^{\mathrm{ad}}$ & $4.29 \pm 0.31^{\mathrm{ad}}$ \\
\hline IV. & $\mathrm{CCl}_{4}+200 \mathrm{mg} / \mathrm{kg}$ bw of J. c extract & $5.91 \pm 0.15^{\text {ad }}$ & $3.55 \pm 0.53^{\mathrm{ad}}$ \\
\hline $\mathrm{V}$ & $\mathrm{CCl}_{4}+500 \mathrm{mg} / \mathrm{kg}$ bw of J. c extract & $7.15 \pm 0.83^{\mathrm{ad}}$ & $4.36 \pm 0.45^{\mathrm{ad}}$ \\
\hline VI. & $\mathrm{CCl}_{4}+1000 \mathrm{mg} / \mathrm{kg}$ bw of J. c extract & $7.32 \pm 0.47^{\mathrm{bd}}$ & $4.79 \pm 0.58^{\mathrm{bd}}$ \\
\hline VII & $\mathrm{CCl}_{4}+$ Silymarin & $7.59 \pm 0.25^{\mathrm{ad}}$ & $4.65 \pm 0.12^{\mathrm{bd}}$ \\
\hline
\end{tabular}

$\mathrm{n}=5$ rats in each group. $\mathrm{p}<0.05$ were considered significant. Values are expressed as mean \pm standard deviation. Values with different superscript (a, b) in the same column are significantly different when comparing other groups with the normal control.

Values with different superscript (c, d) in the same column are significantly different when comparing other groups with the $\mathrm{CCl}_{4}$-treated group. 
Table 4: Effect of methanol extract of Justicia carnea leaves total bilrubin concentration in $\mathrm{CCl}_{4}$-intoxicated rats.

\begin{tabular}{|c|c|c|}
\hline Groups & Treatment & $\begin{array}{l}\text { Mean serum } \\
\text { total Bilirubin } \\
\text { concentration }(\mathrm{mg} / \mathrm{dl})\end{array}$ \\
\hline I. & Feed+water (Normal control) & $0.524 \pm 0.038^{\mathrm{ad}}$ \\
\hline II. & $\mathrm{CCl}_{4} 0.5 \mathrm{ml} / \mathrm{kg}$ bw $\left(\mathrm{CCl}_{4}\right.$-treatedcontrol $)$ & $0.412 \pm 0.049^{\mathrm{bc}}$ \\
\hline III. & Extract alone (extract control) & $0.498 \pm 0.049^{\mathrm{ad}}$ \\
\hline IV. & $\begin{array}{l}\mathrm{CCl}_{4} 0.5 \mathrm{ml} / \mathrm{kg} \mathrm{bw}+200 \mathrm{mg} / \mathrm{kg} \text { bw of J.c } \\
\text { extract }\end{array}$ & $0.700 \pm 0.051^{\mathrm{bd}}$ \\
\hline $\mathrm{V}$ & $\begin{array}{l}\mathrm{CCl}_{4} 0.5 \mathrm{ml} / \mathrm{kg} \mathrm{bw}+500 \mathrm{mg} / \mathrm{kg} \text { bw of J.c } \\
\text { extract }\end{array}$ & $0.662 \pm 0.044^{\mathrm{bd}}$ \\
\hline VI. & $\begin{array}{l}\mathrm{CCl}_{4} 0.5 \mathrm{ml} / \mathrm{kg} \mathrm{bw}+1000 \mathrm{mg} / \mathrm{kg} \text { bw of J.c } \\
\text { extract }\end{array}$ & $0.59 \pm 0.046^{\mathrm{ad}}$ \\
\hline VII & $\mathrm{CCl}_{4}+\mathrm{Silymarin}$ & $0.714 \pm 0.11^{\mathrm{bd}}$ \\
\hline
\end{tabular}

$\mathrm{n}=5$ rats in each group. $\mathrm{p}<0.05$ were considered significant. Values are expressed as mean \pm standard deviation. Values with different superscript $(a, b)$ in the same column are significantly different when comparing other groups with the normal control.

Values with different superscript (c, d) in the same column are significantly different when comparing other groups with the $\mathrm{CCl}_{4}$-treated group.

showed the normal hepatic histo-architecture for laboratory rats. Normal hexagonal; mono-nucleate to bi-nucleate hepatocytes arranged in interconnecting cords (black arrow) were observed. The hepatic cords were arranged in a radiating manner, around the central veins. The portal areas showed the normal constituents of the portal triads (hepatic artery, hepatic vein and bile duct); Portal area (P); H\&E x160 (Figure 3).

The sections of the liver collected from the animals in this group showed a widespread coagulative necrosis of the hepatocytes with mild fibrosis of the peri-lobular connective tissues (white arrow). normal hepatic cords (black arrow); necrotic hepatocytes (blue arrow); Portal area (P); H\&E x160 (Figure 4).

Section of the liver collected from the animals in this group showed a moderate to severe vacuolar degeneration and necrosis of the hepatocytes (arrow). The degenerate hepatocytes show varying sizes of clear vacuoles in their cytoplasm while the necrotic hepatocytes show pyknosis of the nuclei and coagulation of the cytoplasm; H\&E x160 (Figure 5).

Sections of the liver collected from the animals in this group showed coagulative necrosis of the hepatocytes around the portal areas (black arrow) while the other hepatocytes in the mid-zonal and centrilobular areas appear relatively normal (white arrow); H\&E x160 (Figure 6).

The sections of the liver collected from the animals in this group showed a mild fibrosis of the peri-lobular connective tissues (arrow). Central vein (V); Portal area (P); H\&E x160 (Figure 7).

\section{DISCUSSION}

Carbon tetrachloride is metabolized in the liver into highly reactive trichloromethyl radical which leads to auto-oxidation of the fatty acids present in the cytoplasmic membrane phospholipids and causes functional and morphological changes in the cell membrane $[14,20]$. The result of this study clearly indicated hepatoprotective effect of the methanol extract of Justicia carnea leaves extract against carbon tetrachloride-induced hepatotoxicity in albino rats.

Aspartate aminotransferase (AST), Alanine aminotransferase
(ALT), alkaline phosphatase (ALP) are liver enzymes that play important roles in metabolism. Aspartate aminotransferase (AST) catalyses the reductive transfer of amino group from aspartate to a-ketoglutarate to yield oxaloacetate and glutamate. Alanine aminotransferase (ALT) plays an important role in gluconeogenesis and amino acid metabolism. It catalyses the reductive transfer of an amino group from alanine to $\boldsymbol{\alpha}$-ketoglutarate to yield glutamate and pyruvate. Alanine aminotransferase activity is the most frequently relied biomarker of hepatotoxicity [21]. Elevated serum activity of this enzyme is usually observed during liver damage [22]. Alkaline phosphatase (ALP) on the other hand, is a hydrolase enzyme that hydrolyses monophosphates to alkaline $\mathrm{pH}$. It is particularly present in cells which line the biliary ducts of the liver. Hepatotoxicity leads to elevation of the normal values of these enzymes due to the body's inability to secrete it through bile which from congestion or obstruction of the biliary tract that may occur within the liver [23]. These marker enzymes are cytoplasmic in origin and are released into the circulation after cellular damage [24].

Treatment of rats with $\mathrm{CCl}_{4}$ resulted in a significant hepatic damage as indicated by elevated serum levels of liver marker enzymes (AST, ALT and ALP) as observed in this study. There was a significant increase in serum AST, ALT and ALP activities in the group treated with $\mathrm{CCl}_{4}$ alone when compared with the normal control, indicating that the $\mathrm{CCl}_{4}$ was able to reach the liver and induce a detectable damage. These observations are in agreement with the observations of previous study [14]. It has been reported that antioxidant activity or inhibition of the generation of free radicals are important in protection against $\mathrm{CCl}_{4}$-induced liver lesion [25]. The result of this study indicated that rats pre-treated with different doses $(200,500$ and 1000) $\mathrm{mg} / \mathrm{kg}$ bw of the methanol leaf extract Justicia carnea showed lower levels of serum liver marker enzymes (AST, ALT and ALP) when compared with rats that received $\mathrm{CCl}_{4}$ alone. The presence of these antioxidants may have protected the liver of these animals from toxic stress caused by $\mathrm{CCl}_{4}$, which suggested that the decrease in the enzymes activities observed might be due to the presence of antioxidants in the plant which protected the hepatocyte membrane from damage. It may also be possible that the extract stabilized the plasma membrane or repaired the hepatic tissue injuries caused by $\mathrm{CCl}_{4}$ and prevented leakage of the enzyme to the extracellular space [26]. Silymarin also confers hepatoprotective effect by free radical scavenging and also by inhibition of CYP450 system, and hence improve membrane integrity [27,28], this can explain the reduction in serum ALT, AST and ALP activities observed in this study when compared the group treated with silymarin withe $\mathrm{CCl}_{4}$-treated control group. The methanol extract of Justicia carnea might have worked by the same mechanism as sillymarin since similar observation was recorded in groups treated with the extract when compared with the $\mathrm{CCl}_{4}$ treated control group.

Bilirubin is an endogenous anion derived from the degradation of Haem and is excreted in the liver in bile. It is normally present in the blood in small amounts, but it is elevated when there is obstruction or damage in the hepatobiliary duct. This is because the liver cells, when damage, may not be able to excrete bilirubin properly [23]. This can explain the elevated bilirubin concentration observed in the $\mathrm{CCl}_{4}$-treated control as against the normal control. The groups treated with doses of Justicia carnea leaves extract showed significant reduction in total bilirubin level when compared with untreated group. This indicates that the Justicia carnea extract must have improved hepatobiliary clearance by some mechanism or that the extract may have protected the hepatobiliary tract from damage. 
This is in accordance with the findings of previous study [14].

Albumin (ALB) and other blood proteins are primarily synthesized in the liver. Albumin serves as a carrier for molecules of low water solubility including hormones, bile salts, unconjugated bilirubin, free fatty acids, calcium and some drugs. The functional role of ALB makes it a reliable marker for diagnosis of liver disease [29]. Serum proteins (also blood or plasma proteins) are proteins present in blood that serve many different functions, including transport of lipids, hormones, vitamins and minerals in the circulatory system and the regulation of acellular activity and functioning of the immune system. Low serum levels of albumin may be an indicator for hepatotoxicity or liver disease. When the liver becomes damaged or injured, the hepatocytes may not be able to synthesize the proteins efficiently, hence, leading to the reduction in serum concentration of albumin and total protein (TP). Reduction of Albumin and total protein by $\mathrm{CCl}_{4}$ is a further indication of liver damage. Carbon tetrachloride causes a disruption and disassociation of polyribosomes and endoplasmic reticulum which leads to reducing the biosynthesis of protein [30], this explains the reduction in concentration of serum albumin and total protein observed in rats treated with $\mathrm{CCl}_{4}$ alone when compared with the normal control in this study. The decrease could have resulted from a concomitant decrease in the number of cells responsible for ALB synthesis in the liver, this result is also in agreement with a study [31]. However, treatment with different doses of the methanol extract of Justicia carnea leaves, significantly reversed the reduction in serum albumin and TP levels, increasing the concentration near the value obtained in the normal control, this implies that the extract may have protected the liver cells from damage or reduced level of oxidative damage done to the cells by $\mathrm{CCl}_{4}$ and so reduced the number of damaged hepatocytes by reducing cellular membrane damage [26].

\section{CONCLUSION}

From the results of this study, it can be deduced that Justicia carnea leaves extract may exhibit hepatoprotective properties and so, may be a potential source of drugs for the treatment of liver damage and toxicity.

\section{REFERENCES}

1. Fasuyi AO. Nutritional potentials of some tropical vegetable leaf meals. Chemical characterization and functional properties. Afr J Biotechnol. 2006;5:49-53.

2. Kumar EP, Kumar AD, Parasuraman S, Raman VR, Emerson SF. Hepatoprotective activity of clearliv a polyherbal formulation in wistar rats. Archives Med Health Sci. 2013;1:120-125.

3. Ahsan R, Islam M, Bulbul JI, Musalddik A, Hague E. Hepatoprotective activity of methanol extract of some medicinal plants against carbon tetrachloride-induced hepatotoxicity in rats. Eur J Scientific Res. 2009;37:302-310.

4. Oze G, Nwanjo H, Oze R, Akubugwo E, Orisakwe E, Aka PV. Reproductive impairment associated with the ethanolic extract of Alstonia boonei (De-Wild) stem bark in male rats. Internet J Laboratory Med. 2007;3:1-10.

5. Chattopadhyay RR, Bandyopadhay M. Effects of Azadiradita leaf extract on serum Lipid profile in normal and streptozotocin induced diabetic rats. African J Biomedical Res. 2005;8:101-104.

6. Navarro VJ, Senior JR. Drug-related hepatotoxicity. N Engl J Med. 2006;354:731-739.
7. Aashish P, Tarun S, Palkvi B. Drug-induced Hepatotoxicity: A review. J Applied Pharmaceutical Sci. 2012;2:233-243.

8. Saukkonen JJ, Cohn DL, Jasmer RM, Schenker S, Jereb JA, Nolan CM. An Official ATS Statement: Hepatotoxicity of anti-tuberculosis therapy. Am J Respir Crit Care Med. 2006;174:935-952.

9. Onyeabo C, Achi NK, Chima AE, Ebere CU, Okoro CK. Haematological and biochemical studies on Justicia carnea leaves extract on phenylhydrazin induced anemia in albino rats. Acta Sci Pol Technol Aliment. 2017;16:217-230.

10. Badami S, Aneesh R, Sankar S, Sathishkumar MN, Suresh B, Rajan S. Antifertility activity of Derris brevipes variety coriacea. J Ethnopharmacol. 2003;84:99-104.

11. Correa GM. Chemical constituents and biological activities of species of Justicia: A review. Brazillian J Pharmacognosy. 2012;122:220-238.

12. Radhika J, Sathya S, Jothi G, Japasheba JL. Cardioprotective role of Justicia traquebareinsis Linn. leaf extract in isoproterenol induced myocardial infarction in albino rats. J Applied Pharmacological Sci. 2013;3:124-128.

13. Medapa S, Singh GRJ, Ravikumar V. The phytochemical and antioxidant screening of Justicia wynaadensis. Afr J Plant Sci. 2011;5:489-492.

14. Patrick-Iwuanyanwu KC, Wegwu MO. Prevention of carbon tetrachloride $\left(\mathrm{CCl}_{4}\right)$-induced liver damage in rats by Acanthus Montana. Asian J Biochemistry. 2008;3:213-220.

15. Reitman S, Frankel S. Method of Alanine and Aspartate Amino Transferase Determination. American J Clinical pathology. 1957;28:56-67.

16. King EJ, Armstrong AR. A convenient method of determining serum and bile phosphate activity. Can Med Assoc J. 1934;31:376-381.

17. Jendrassik L, Grof P. Estimation of serum total bilirubin level by spectrophotometry on serum and plasma. Biochemical Zeitschrpt 1983;297:81-89.

18. Weichselbaum TE. Accurate and rapid method for the determination of proteins in small amounts of blood serum. Am J Clin Pathol. 1946;10:40-49.

19. Doumas BT, Watson WA, Briggs HG. Albumin standards and the measurement of serum albumin with bromocresol green. Clin Chim Acta. 1971;31:87-96.

20. Recknagel RO. Carbon tetrachloride hepatotoxicity. Pharmacol Rev. 1967;19: 145-208.

21. Amacher DE. A toxicologist's guide to biomarkers of hepatic response. Hum Exp Toxicol. 2002;21:253-262.

22. Dufour DR, Lott JA, Nolte FS, Gretch DR, Koff RS, Seeff LB. Diagnosis and monitoring of hepatic injury: II. Recommendations for use of laboratory tests in screening, diagnosis and monitoring. Clin Chem. 2000;46:2050-2068.

23. Singh A, Bhat TK, Sharma OP. Clinical Biochemistry of Hepatotoxicity. J Clinic Toxicol 2011;S4:001.

24. Lin SC, Chung TC, Ueng TH, Lin YH, Hsu SH, Chiang CL, et al. The hepatoprotective effects of Solanum alatam moech on acetominopheninduced hepatotoxicity in mice. Am J Chin Med. 2008;28:105-114.

25. Attri S, Rana SV, Vaiphie K, Katyal R, Sodhi CP, Kanwar S, et al. Protective effect of $\mathrm{N}$-acetyl-cysteine in isonaizid-induced hepatic injury in growing rats. Indian J Exp Biol. 2003;39:436-440.

26. Sadeghi H, Hosseizadah S, Akbartabar M, Ghavamzaeh M, Jafari Barmak M, Sayahi M, et al. Hepatoprotective effect of Rosa caina fruit extract against carbon tetrachloride induced hepatotoxicity in rat. Avicenna J Phytomed. 2016;6:181-188. 
27. Muriel $P$, Mourelle M. Prevention by silymarin of membrane alterations in acute $\mathrm{CCl}_{4}$ liver damage. J Appl Toxicol. 1990;10:275-279.

28. Baer-Dubowska W, Szafer H, Krajkakuzniak V. Inhibition of murine hepatic cytochrome P450 activities by natural and synthetic phenolic compounds. Xenobiotica. 1998;28:735-743.

29. Benoit SC, Morell JR, Davidson TL. Lesions of the Amygdala Central Nucleus Interfere with Blockade of Satiation for Peanut Oil by Na-2Mercaptoacetate. Psychobiology. 2000;28:387-393.
30. Sathesh Kumar SI, Ravi Kumar B, Krishna Mohan G. Hepatoprotective effect of Trichosanthes cucumerina Var cucumerina L on carbon tetrachloride induced liver damage in rats. J Ethnopharmacol. 2009; 123:347-350.

31. Omotuyi IO, Nwangwu SC, Okugbo OT, Okoye O, Ojieh GC, Wogu DM. Hepatotoxic and hemolytic effects of acute exposure of rats to artesunate overdose. African J Biochemical Resources. 2008;2:107110. 